\title{
STUDIES ON COLONISATION OF FLY ASH DISPOSAL SITES USING INVASIVE SPECIES AND AROMATIC GRASSES
}

\author{
Deblina MAITI, Bably PRASAD \\ Natural Resources and Environment Management, CSIR - Central Institute of Mining and \\ Fuel Research, Dhanbad, India \\ Academy of Scientific and Innovative Research (AcSIR), CSIR - Central Institute of Mining and \\ Fuel Research, Dhanbad, India
}

Submitted 15 Mar. 2016; accepted 24 Aug. 2016

\begin{abstract}
Fly ash disposal activities by coal based thermal power plants will continue to be a serious issue across the globe due to its hiked generation every year. To obviate the hazardous effects of fly ash disposal sites on the surrounding ecosystems, rapid stabilization of the dumps is essential. This paper conglomerates the past activities, challenges; present scenario of vegetation establishment on these sites as well as future research requirements based on various experimental case studies. An insight has been presented on the usefulness of native, tuft, aromatic grasses which can reduce the length of successive phases in reclamation programmes and also enhance the fertility of the substrate as found from the significantly increased nitrogen content in the present field sites. Metal bioaccumulation studies depicted that by virtue of high biomass production potential of Saccharum spontaneum it can also be used as a phytoextractor of toxic metals, thus helping in phytoremediation of the metals in fly ash. Field studies allude the fact that knowledge of phytodiversity of old fly ash deposits is essential for a right choice of species before every reclamation programme. Secondly, application of amendments is conjointly a prerequisite for establishment of plants on fly ash. In a pot scale study it was found that lower rate of amendment application (2-5\% farmyard manure and $5-10 \%$ topsoil on weight basis) in fly ash improves the growth and biomass of Cymbopogon citratus. Extensive root system of the grass was substantiated by high root: shoot biomass which stabilized the surface of the ash. To investigate the possibilities of ground water contamination due to amendments leaching studies were carried out. An initial high concentration of some ions marginally near permissible limit as per Indian drinking water standards was observed but their concentrations were below acceptable limit during harvestable stages. Above studies can contribute significantly in field studies through a properly planned restoration programme.
\end{abstract}

Keywords: nitrogen, biomass, farmyard manure, cymbopogon citratus, saccharum spontaneum, bioaccumulation.

Online supplementary material: Supporting information for this paper is available as online supplementary material at https://doi.org/10.3846/16486897.2016.1231114

\section{Introduction}

Fly ash is the main industrial waste product generated by coal based thermal power plants. India ranks third across the globe in fly ash production (Ram et al. 2008). Fly ash generation is likely to surpass 300 MT by the year 2017 due to very high ash content of the coal, which is about 35-45\% (Mathur et al. 2003). Year 2012-2013 experienced a standing amount of 63 million tonnes of unutilized ash (37\% of the total ash produced) in India which was dumped, encroaching a land area of more than $40000 \mathrm{Ha}$ (Jain, Gaggar 2013). Fly ash is generally being disposed off in low lying areas, landfills, basins around thermal power plants and in abandoned mine pits (CEA 2012). These dumps have deleterious effects and contaminates nearby aquatic and terrestrial ecosystems. Furthermore in the long run, trace metals in fly ash contaminate ground water and get into living organisms through food chain (Belyaeva, Haynes 2012). Thus there is an urgent need for stabilization of the dumps.

In this context, phytomanagement is the most effective and eco-friendly approach as it stabilizes ash dumps, reduces erosion and incurs gradual restoration of the site. It also reduces gradual leaching of water and solutes into ground water and initiates carbon sequestration. They also

Corresponding author: Deblina Maiti

E-mail: dmhellodeblina@gmail.com 
pave the pathway for future generation of bio-resource (Pandey 2012). This paper conglomerates the past and present status of revegetation of fly ash disposal sites. It also highlights the challenges and future research needs which should be focused on in this aspect. Furthermore an insight has been presented in the usefulness of grasses in stabilization of fly ash dump surfaces. Native hardy and tuft grasses are early colonizers as they can thrive on adverse conditions. With a view of long term management the information collected here will contribute a substantial part on an effective strategy for fly ash dump stabilization.

\section{Earlier studies on reclamation of fly ash disposal sites}

Vegetation cover development on fly ash disposal sites is difficult at early stages. Fly ash consists of glass-like spherical particles, with a silty loam texture and a natural compaction tendency which inhibits water infiltration as well as restricts root growth to some extent (Haynes 2009). Though, it has high moisture retention capacity, and considerable amounts of plant nutrients $(\mathrm{Ca}, \mathrm{K}, \mathrm{Mg}, \mathrm{Cu}, \mathrm{Fe}$, $\mathrm{Mn}, \mathrm{Mo}, \mathrm{Zn}, \mathrm{B}$ ) in the form of oxides, hydroxides, carbonates and bicarbonates; it lacks microbial activity, and a consistent supply of nitrogen crucial for plant growth (Page et al. 1979). Besides, it also contains various toxic metals such as $\mathrm{V}, \mathrm{Cr}, \mathrm{Ni}, \mathrm{As}, \mathrm{Se}, \mathrm{Rb}, \mathrm{Sr}$ and $\mathrm{Pb}$ which can get its path into higher trophic level through food chain. Various authors have carried out their studies on a number of herb, shrub, grass as well as tree species as enumerated in Table 1. Generally, efficient, stress tolerant, fast growing species which can help in development of a quick cover are recommended. Zolnierz et al. (2016) has recently reported the phytodiversity of an abandoned mine filled with fly ash, 11 years after reclamation. Inclusion of native plants in presence of microbial amendments has been reported by many workers (Krzaklewski et al. 2012; Babu, Reddy 2011; Hrynkiewiez et al. 2009). Few workers have studied the effect of sandy topsoil/farmyard manure/mill mud/compost/biosolids/sewage sludge/vermiculite on ash to support revegetation (Cheung et al. 2000). Studies on field practices of revegetation usually involve high rate of fertilizer addition in absence of topsoil. According to agronomic techniques NPK (nitrogen:phosphorus:potassium) fertilizers are generally used in the ratio of 15:15:15 or 19:19:19 to a root tilled depth of $15 \mathrm{~cm}$, (Punshon et al. 2002). But high rate fertilizer addition incorporates a great deal of ions and solutes which can erode into the nearby water streams or seep through the ground to contaminate water below in the long run. A cost effective amendment approach is still lacking at the current state to be implemented in the field. Thus, an effort has been made by us in a recent study to grow aromatic grasses as initial colonizers in presence of low rate of amendment application.
Table 1. Plant species used for vegetation establishment on fly ash dumps

\begin{tabular}{|c|c|c|}
\hline Species name & Habitat & Reference \\
\hline $\begin{array}{l}\text { Parthenium } \\
\text { hysterophorus }\end{array}$ & Herb & Dwivedi et al. (2008) \\
\hline Solanum nigrum & Herb & Dwivedi et al. (2008) \\
\hline Limnanthes spp & Herb & Dwivedi et al. (2008) \\
\hline Eclipta alba & Herb & Dwivedi et al. (2008) \\
\hline Typha latifolia & Herb & Maiti and Jaiswal (2008) \\
\hline Fimbristylis dichotoma & Herb & Maiti and Jaiswal (2008) \\
\hline Amaranthus defluxes & Herb & Maiti and Jaiswal (2008) \\
\hline Cassia tora & Herb & Gupta and Sinha (2008) \\
\hline Chenopodium album & Herb & Gupta and Sinha (2008) \\
\hline Blumea lacera & Herb & Gupta and Sinha (2008) \\
\hline Equisetum ramosysma & Grass & Dwivedi et al. (2008) \\
\hline Saccharum munja & Grass & Dwivedi et al. (2008) \\
\hline Saccharum spontaenum & Grass & Maiti and Jaiswal (2008) \\
\hline Cynodon dactylon & Grass & Maiti and Jaiswal (2008) \\
\hline Calamagrostis epigejos & Grass & Mitrovic et al. (2008) \\
\hline Festuca rubra & Grass & Mitrovic et al. (2008) \\
\hline Calotropis procera & Shrub & Gupta and Sinha (2008) \\
\hline Ipomoea Carnea & Shrub & Pandey (2012) \\
\hline Ricinus Communis & Shrub & Pandey (2013) \\
\hline Sida cardifolia & Shrub & Gupta and Sinha (2008) \\
\hline Acacia auriculiformis & Tree & Cheung et al. (2000) \\
\hline Alnus glutinosa & Tree & Jamil et al. (2009) \\
\hline Alnus incana & Tree & Jamil et al. (2009) \\
\hline Cassia seamea & Tree & $\begin{array}{l}\text { Juwarkar and Jambulkar } \\
(2009)\end{array}$ \\
\hline Jatropha curcas & Tree & Krzaklewski et al. (2012) \\
\hline Leucaena leucocephala & Tree & Cheung et al. (2000) \\
\hline Prosopis juliflora & Tree & Rai et al. (2004) \\
\hline
\end{tabular}

\section{Material and method}

\subsection{Field investigations and sampling}

Field surveys were conducted on different aged fly ash disposal sites in and around Jharkhand and West Bengal state of India during dry periods of the year 2015. Approximately, six to seven visibly dominant plant species were selected for sampling. Three replicates for each of the dominant plant species and their rhizospheric fly ash samples $($ depth $=30 \mathrm{~cm}$ ) were collected from each site. The replicates for each plant species were chosen on the basis of same age group. All the samples were collected in clean labeled plastic bags and transported to the laboratory for analysis. Encountered plants were identified with the help of related flora. Descriptions of the sites chosen for study are given below.

Study site 1 is located in low lying lands around Tenughat Thermal Power station. It is situated near 
Tenughat Dam in the district of Bokaro, Jharkhand India. The total capacity of the plant is $1550 \mathrm{MW}$ and it encroaches an area of 2200 acres which also includes low lying areas for fly ash disposal. Fly ash disposal is generally followed by compaction through heavy machinery and covering with live topsoil acquired from nearby areas. Presence of rich biodiversity in the nearby areas helps in succession of disposal sites with native invasive species in a period of 1 year which generally accelerates after monsoon. Site 2 is located in the abandoned, opencast fly ash filled mines of Damoda located in Dhanbad district of Jharkhand state in India. Fly ash used for filling the mines was taken from nearby Chandrapura thermal power plant of $890 \mathrm{MW}$ capacities located $16 \mathrm{~km}$ away from the mines. The process of filling was carried out for 3 years to create a dump of fly ash which is now covered with native and invasive grasses. Study site 3 is another fly ash dump located inside Crescent thermal power plant premises near Asansol, West Bengal India. The thermal power station is of $40 \mathrm{MW}$ and the primary fuel is washery rejects obtained from the same premises. The dump is present in an area of 4-5 hectare of land. The reclamation programme of the dump was commenced with technical steps such as topsoiling to a thickness of about $60 \mathrm{~cm}$, construction of permanent drainage channels along the slopes, garland drain at dump foot ultimately leading to a reservoir. In pit plantation of trees were done along with seeding with native grass legume species. The average annual rainfall of the entire zone is $1200-1300 \mathrm{~mm}$ while the temperature varies from $10-40{ }^{\circ} \mathrm{C}$ annually. Site 1 and 2 was chosen to account for the natural succession of fly ash disposal sites and identify the dominant plant species. Site 3 was taken as a reference site in contrast to site 1 and 2 wherein a technical restoration programme had been followed. The results of site 1 and 2 were compared to site 3 in this study.

\subsection{Experimental design for pot scale study}

Fly ash (FA) for the pot scale study was collected from the ash ponds near Chandrapura thermal power plant of Damodar Valley Corporation located at Chandrapura town in Jharkhand state of India. Garden soil (GS) was collected from top $15 \mathrm{~cm}$ from the Institute's garden at CSIR-CIMFR, Dhanbad located in Jharkhand state of India. Farmyard manure (FYM) was obtained from a nearby dairy farm. All the samples were air dried for a week, thoroughly mixed and grounded to pass through a $4 \mathrm{~mm}$ sieve.

Garden soil and farmyard manure were mixed with fly ash on weight basis, in proportions of $5 \%, 10 \%$ and $2 \%, 5 \%$ respectively. Treatment I was the control with no amendments while treatments IV (FA + 5\% GS + 2\% FYM), V (FA + 10\% GS + 2\% FYM), VI (FA + 5\% GS + $5 \% \mathrm{FYM})$, and VII (FA + 10\% GS + 5\% FYM) had been prepared with different combinations of garden soil and farmyard manure. The resultant treatments had a $\mathrm{pH}$ near 7.00 at initial stage which usually doesn't pose any threat of metal contamination. The pots containing the mixtures were arranged for equilibration under natural light and temperature for 10 weeks. After equilibration period, first leachate (1L) collection was done while second (2L) and third leachates (3L) were collected at intervals of 2 months till final harvest of the plants near after 4 months. Leachate collection from the pots had been done, based on the design of Marseille et al. (2000). It was mainly done to investigate the contribution of amendments and vegetation on the amount of ions and metals leaching down which may contaminate the ground water. This was followed by plantation of 2-3 Cymbopogon citratus tillers per pot. Regular irrigation of the pots was done five - six times a week with equal amounts of water and recorded. The collected leachate samples were immediately taken to the laboratory for analysis. In an economical point of view C. citratus shoots are generally harvested after 3.5-4 months for oil extraction (Maiti, S. K., Maiti, D. 2015; Maiti, Prasad 2016). With this point in view, the plants in this study were harvested at maturity near after 4 months.

\subsection{Analysis of samples}

The root and shoot parts of the plants were segregated in the laboratory to determine their biomass. Average weight of all the plants from each site was calculated individually. They were repeatedly washed with tap water and deionized water to remove all the adhered fly ash particles followed by drying to a constant weight at $80^{\circ} \mathrm{C}$ in oven and finally grinding to a fine powder for heavy metal analysis. Powdered samples of a known weight were reduced to ashes at $450{ }^{\circ} \mathrm{C}$ for $45 \mathrm{~min}$ and $850{ }^{\circ} \mathrm{C}$ for $1 \mathrm{~h}$, followed by dissolution in $25 \mathrm{ml}$ of $6 \mathrm{M} \mathrm{HNO}_{3}$ and subsequent digestion. The solutions were filtered with Whatman 42 grade filter paper into $50 \mathrm{ml}$ volumetric flasks (Rodriguez et al. 2011) followed by metal analysis through atomic absorption spectrophotometer (Thermo Scientific, Germany).

Fly ash samples were air-dried and ground to pass through a $2 \mathrm{~mm}$ sieve, for analysis of $\mathrm{pH}$ in 1:1 ratio $(\mathrm{w} / \mathrm{v})$ with distilled water (Jackson 1973), loss on ignition at $450{ }^{\circ} \mathrm{C}$ and $750{ }^{\circ} \mathrm{C}$ respectively in a muffle furnace for 1 hour each (Mishra, Das 2010; ASTM D 2974-87). Determination of available nitrogen was done by the method of Subbiah and Asija (1956) while water holding capacity was done through keen's box method (Piper 1942).

The leachate samples were analyzed for $\mathrm{pH}, \mathrm{EC}$ (electrical conductivity), TH (total hardness), $\mathrm{Ca} \mathrm{H}$ (calcium hardness), $\mathrm{Cl}$ (chloride), TDS (total dissolved solid), total alkalinity (Tot Alk), and $\mathrm{SO}_{4}$ (sulphate) as per standard methods (APHA, AWWA, WEF 1992; IS-3025 2009). 
Sample preparation was done before metal analysis. Approximately, $200 \mathrm{ml}$ samples of each leachate was acidified using concentrated nitric acid and digested on a hot plate at $70{ }^{\circ} \mathrm{C}$ to a volume less than $50 \mathrm{ml}$. The digested and concentrated sample was filtered through Whatman cellulose filters, pore size $0.45 \mu \mathrm{m}$ using sterile injectors into $50 \mathrm{ml}$ volumetric flasks. The volumes were made up to $50 \mathrm{ml}$ with distilled water. Analysis of each metal was done at respective sensitive wavelength i.e. at 324.7, 279.5, 217.0, 228.8, 213.9, 232.0 and $357.9 \mathrm{~nm}$ for $\mathrm{Cu}, \mathrm{Mn}, \mathrm{Pb}$, $\mathrm{Cd}, \mathrm{Zn}, \mathrm{Ni}$ and $\mathrm{Cr}$ respectively. Limits of detection of various metals ( $\mathrm{Mn}, \mathrm{Zn}, \mathrm{Cu}, \mathrm{Pb}, \mathrm{Cd}, \mathrm{Cr}$, and $\mathrm{Ni}$ ) were in the range of 0.0005 to $0.01 \mathrm{mg} \mathrm{L}^{-1}$. The calculations for metals in leachates were done by dividing the instrument reading for metals by concentration factor. Blanks and different dilution standards were used for calibration and quality assurance. The instrument was recalibrated after analysis of 15 samples. All the glassware used for analysis were acid washed and rinsed with distilled water, dried and kept in a clean dry environment prior to use. All reagents used were of analytical grade (Merck).

\subsection{Statistical analysis}

Statistical analyses were carried out to interpret the results by using SPSS (version 20.0 for Windows; SPSS Inc. Chicago, USA) and MS Excel 2010. Mean values along with their standard deviation (SD) has been computed and have been shown as error bars in the graphs. Descriptive statistics like one way analysis of variance was used to access the variance between the means of an analyzed parameter between the sampling sites and leachates from the pot study. Difference between individual means was carried out through DMRT (Duncan's multiple range test) model at 95\% level of confidence. Hierarchical cluster analysis is performed on dataset of metal concentrations to group similar metal clusters using Eucledian distance and group

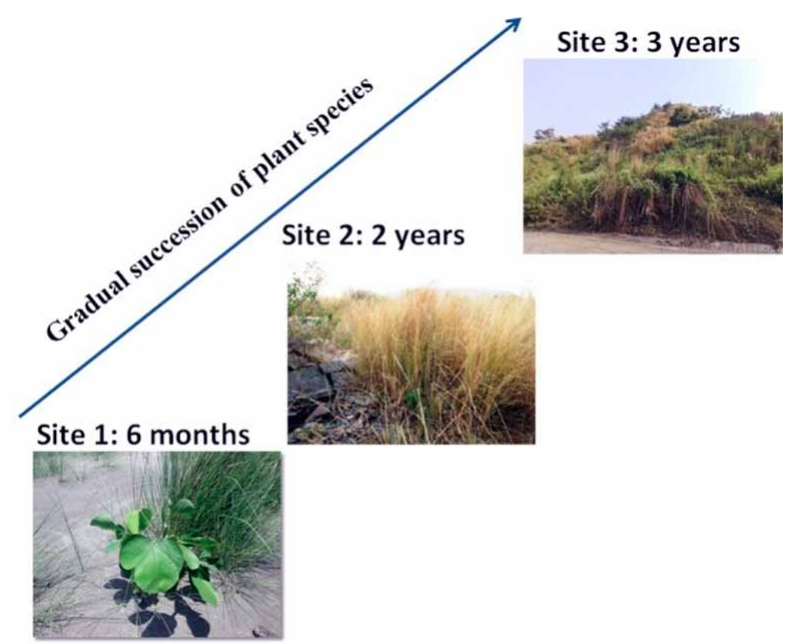

Fig. 1. Plant cover establishment in different fly ash dump sites linkage methods. Relation between general water quality measures and metal associations and their relations to $\mathrm{pH}$ have also been performed tested with two-tailed as well as one tailed Pearson correlation to get a matrix of correlations between them.

\section{Result and discussion}

\subsection{Vegetation succession on fly ash disposal sites}

Various field surveys done by us has revealed that natural colonisation of fly ash surfaces depend on the nutrient content of the substrate, efficiency of plant species to grow in adverse conditions and interactions between them (Belyaeva, Haynes 2012). The three field sites chosen by us varied in the age of the vegetation and were of 6 months, 2 years, and 3 years respectively (Fig. 1). Initial colonisation of the sites are dominated by weed herbs such as Chromolaena odorata, Dysphania ambrosioides, Sida rhombifolia, Tephrosia purpurea various shrubs and grasses as seen in site 1. At later stages hardy and tuft grasses cover the areas which were observed in site 2. A proper restoration program (such as topsoil blanketing, addition of amendments and seeding with native species) was followed in the $3^{\text {rd }}$ field site (reference site) which showed the presence of more various plant species after 3 years of vegetation. The vegetation cover of more than a meter in site 3 was dominated by Saccharum spontaneum, Ipomoea sp., and Pennisetum pedicellatum. Presence of few number of tree species were also found on the dump slopes. It was recovered from the site authorities that during initiation of closure activity 2500 number of tree species were planted out of which a very few percent has survived till the present date. The slope length of the present reclaimed dump was 35-40 $\mathrm{m}$ with an angle of 55 degrees.

A noticeable fact as found in all the three sites was the dominance of Saccharum spontaneum and Cynodon dactylon. These types of results were also obtained by various other authors (Dwivedi et al. 2008; Pandey et al. 2012). These invasive grasses have tolerance to various adverse conditions and shows competitive behaviour towards other species. Narratively, their perennial nature, presence of light persistent seeds and rhizomatous roots imparts the advantage for their invasive nature (Graham et al. 2014). On the other hand they also stabilise the fly ash dump surface by holding on to the loose material through their strong roots (Kaith et al. 2010). Secondly it was also observed that later stages of reclamation of the dumps lacked an economic end use. A major strategy which can be focussed upon in this context is biomass production at later stages of restoration programmes. Few economically important trees which can be included are pulp and paper tree, biodiesel crops, firewood, timber wood and plywood trees. 


\subsection{Rhizospheric fly ash characteristics and plant biomass}

Figure 2 shows the variation in physicochemical properties of the sites. Site 1 and 3 had near neutral $\mathrm{pH}$ and site 2 had an average $\mathrm{pH}$ of 5.6 significantly different from other sites may be due to the mixing of moderately acidic minesoil with fly ash. Previous studies on the groups of nearby opencast mines near site 2 also have revealed a mine soil pH value near 4.18-5.35 (Mukhopadhyay et al. 2013). Available nitrogen in the sites increased significantly with the age of the vegetation from $39-109 \mathrm{mg} \mathrm{kg}^{-1}$. Approximately $64 \%$ of nitrogen increment was observed at the climax of vegetation establishment at site 3. In a study reported by Maiti, S. K., Maiti, D. (2015) a nitrogen level of 34-72 $\mathrm{mg} \mathrm{kg}^{-1}$ was developed under grass legume vegetation while their reference site (nearby forest area) had approximately $100 \mathrm{mg} \mathrm{kg}^{-1}$ of available nitrogen. The presence of dense cover of $S$. spontaneum in site 2 incorporated fine root litter from its extensive root system which may be accountable for the increase in soil nitrogen after 2 years significantly similar to the restored site 3 . Analogous to this the average ground cover biomass of the sites also had a significantly increasing trend (135-400 g per plant) with the age of vegetation (Fig. 3). Loss on ignition of the sites varied significantly from $3.7-18 \%$. High

a)

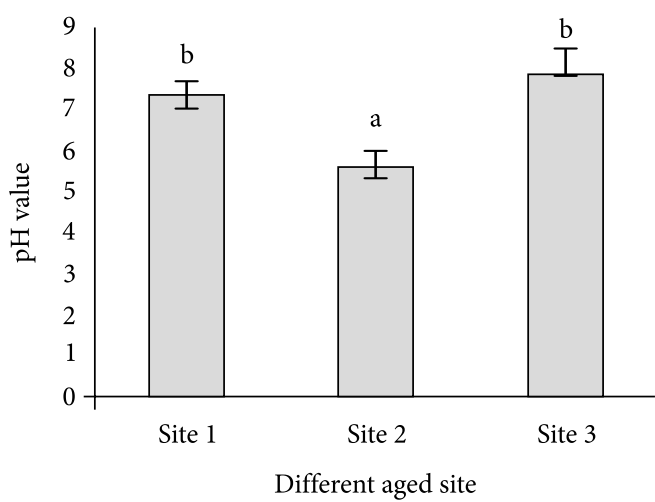

c)

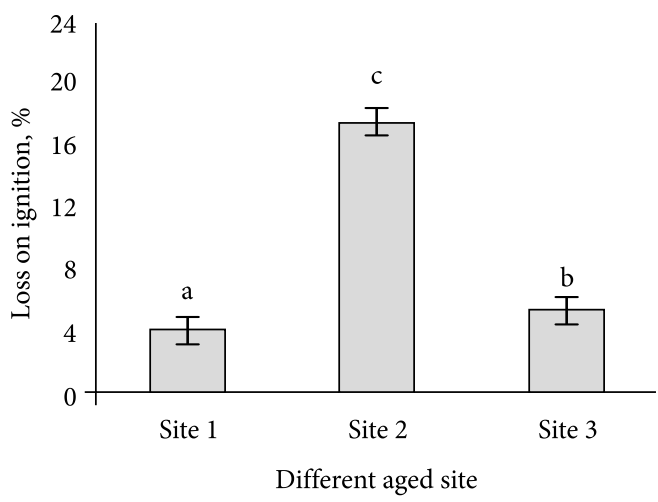

value of loss on ignition in site 2 was probably due to mixing with mine soil. The proof of this statement relies on the fact that the loss on ignition value of the original fly ash (also used for pot scale study in this paper) used for filling the mine pit of site 2 is $5.55 \%$. On the other hand the surface rhizospheric samples of site 1 and 2 had water holding capacity of nearly $64 \%$ while site 3 had a water holding capacity of $38 \%$. The rhizospheric samples from site 3 were predominantly the topsoil which had been used to blanket the fly ash dump prior to the ecorestoration programme. High water holding capacity of fly ash compared to soil is attributed to the large surface area of the spherically shaped particles of fly ash which increases microporosity (Shaheen et al. 2014).

\subsection{Metal accumulation in plants}

Metal accumulation in the dominant plant species growing on two different aged fly ash dumps have been reported based on their yield in Table 2. The metal content in the plants were multiplied with the biomass data. Similar dominant plant species were chosen from the sites undergoing natural succession (site 1 and 2) to differentiate the metal accumulation under different conditions. S. sponatneum has been found to be more efficient and accumulated more amounts of metals than C. dactylon

b)

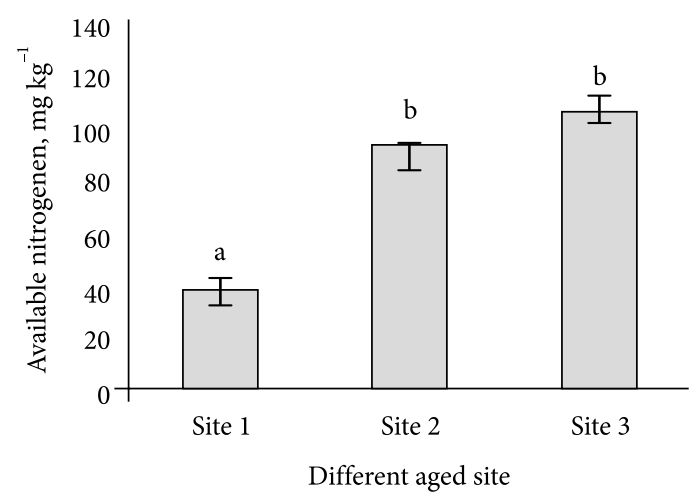

d)

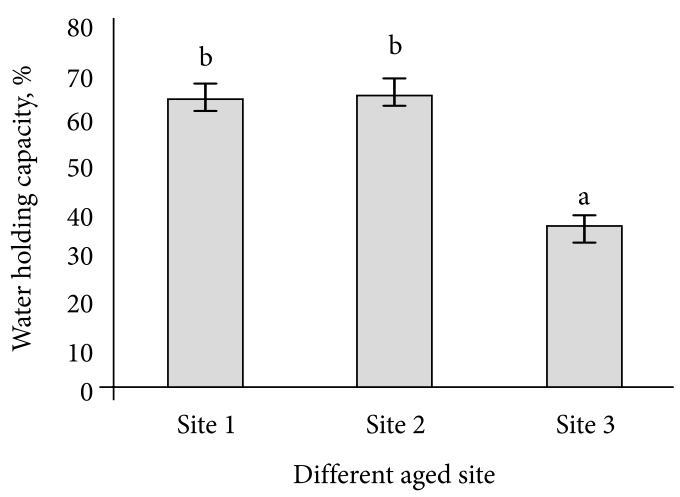

Fig. 2. Physicochemical parameters of rhizospheric samples from different aged fly ash dump sites such as pH (a); available nitrogen (b); loss on ignition (c); water holding capacity (d) for $\mathrm{n}=7$ replicates. The deviation between the data for each individual parameter for a site has been shown as error bars. Different alphabetical letters above each bar for a graph depict significant differences between the means at $\mathrm{p}<0.05$ 
due to its greater biomass. Bioaccumulation factor of $\mathrm{Cr}$ (4.21-77.27) and $\mathrm{Pb}$ (2.20) was found greater than 1 as indicated by bold letters in Table 2. Metal concentration in the plants increased with the age of the vegetation as also obvious from the higher values of metals in S. spontaneum from site 2 than in site 1 . This is also evident from the data that toxic metals such as $\mathrm{Cd}, \mathrm{Ni}, \mathrm{Pb}$, and $\mathrm{Cr}$ content varied from 0.01 to $0.05 \mathrm{mg} / \mathrm{kg}, 1.58$ to $4.14 \mathrm{mg} / \mathrm{kg}$, 0.30 to $0.58 \mathrm{mg} / \mathrm{kg}, 32.34$ to $48.75 \mathrm{mg} / \mathrm{kg}$ in S. sponatneum which is approximately $80-90 \%$ more in site 2 than site 1 . Even though, bioaccumulation factor of $\mathrm{Cr}$ in C. dactylon from site 1 was found highest (77.27) from site 2 (4.21) which are approximately 18 folds that of the later. Further, S. spontaneum also showed a twofold higher bioaccumulation factor for $\mathrm{Cr}$ in site 1 than site 2. Metal accumulation in plants also depends on $\mathrm{pH}$, metal concentration in substrate, and differential response of each species to detoxify metals (Gupta et al. 2002).

Accumulation of metals in plants varied in the order $\mathrm{Cr}>\mathrm{Mn} \sim \mathrm{Zn}>\mathrm{Cu} \sim \mathrm{Ni}>\mathrm{Pb}>\mathrm{Cd}$ and $\mathrm{Mn} \sim \mathrm{Cr}>\mathrm{Zn}$ $>\mathrm{Ni}>\mathrm{Cu}>\mathrm{Pb}>\mathrm{Cd}$ respectively in site 1 and 2 , which

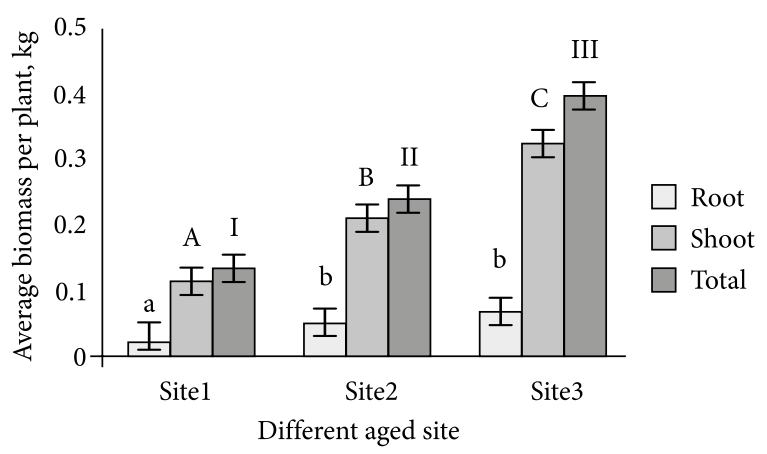

Fig. 3. Average shoot, root and total biomass per plant at different aged fly ash dump sites for $n=7$ replicates. Different lowercase, uppercase and roman letters above each type of bar represent significant difference between the means for the parameter at $p<0.05$ varied irrespective of the concentration of metals in fly ash. This was further proved by Figure 4 showing the dendrogram (between groups) obtained using hierarchical cluster analysis with pearson distance. It helps in showing the pattern of metal accumulation in plants from site 1 and 2. Here, Mn and $\mathrm{Zn}$ are in the same cluster linked with $\mathrm{Cr}$ showing that fly ash is contributing to elevated $\mathrm{Cr}$ levels in plants. Cr has also been found to be linked distantly with $\mathrm{Ni}$ whereas other metals such as $\mathrm{Pb}, \mathrm{Cd}$ and $\mathrm{Cu}$ have been found in separate groups. Linkage of $\mathrm{Cr}$ and $\mathrm{Ni}$ are due to their nature of being transitional elements (Das et al. 2013). Metal accumulation by yield of $\mathrm{Pb}$ and $\mathrm{Cd}$ was found to be low in all the cases inspite of unit bioaccumulation factor of $\mathrm{Pb}$ in C. dactylon. The above results efficiently demonstrate that on virtue of its high biomass production potential S. spontaneum can be used for phytoextraction of some metals and subsequently phytoremediate metal contaminated sites.

\subsection{Growth of aromatic grass on amended fly ash with emphasis on leaching studies}

In an another study we have found that lower rate of amendment application in fly ash such as $2-5 \%$ farmyard manure as well as 5-10\% topsoil enhances the growth and biomass of perennial aromatic grass Cymbopogon citratus. C. citratus, also called lemon grass propagates through old tillers and was chosen for initial plantation in the pots as per literature studies. Maiti, S. K., Maiti, D. (2015) found it to be very promising on waste dumps of a sponge iron plant, in a field study. In this study, the grass grew to a height of more than $50 \mathrm{~cm}$ after 45 days of tiller plantation. It has deep fibrous root system which holds the fly ash particles and prevents its erosion (Fig. 7). A single plant produced approximately 30-40 tillers after 3-4 months of growth which usually follows a sigmoid-shaped curve.

Table 2. Metal accumulation in dominant plant species growing on different aged fly ash dump sites $\left(\mathrm{mg} \mathrm{kg}^{-1}\right)$, bioaccumulation factors, and concentration in the rhizospheric fly ash samples $\left(\mathrm{mg} \mathrm{kg}^{-1}\right)$

\begin{tabular}{|c|c|c|c|c|c|c|c|c|c|}
\hline \multirow{2}{*}{ Parameters } & \multirow{2}{*}{$\begin{array}{c}\text { Field } \\
\text { site }\end{array}$} & \multirow{2}{*}{ Plant species } & \multicolumn{7}{|c|}{ Metal } \\
\hline & & & $\mathrm{Mn}$ & $\mathrm{Cu}$ & $\mathrm{Zn}$ & $\mathrm{Cd}$ & $\mathrm{Cr}$ & $\mathrm{Ni}$ & $\mathrm{Pb}$ \\
\hline \multirow{4}{*}{$\begin{array}{l}\text { Accumulation in plants } \\
\left(\mathrm{mg} \mathrm{kg}^{-1}\right)\end{array}$} & 1 & Cynodon dactylon & 4.60 & 0.53 & 5.35 & 0.01 & 12.17 & 1.04 & 0.46 \\
\hline & 2 & Cynodon dactylon & 9.79 & 0.64 & 3.59 & 0.01 & 6.46 & 0.93 & 0.18 \\
\hline & 1 & Saccharum spontaneum & 7.72 & 3.11 & 6.44 & 0.01 & 32.34 & 1.58 & 0.30 \\
\hline & 2 & Saccharum spontaneum & 28.30 & 2.71 & 13.30 & 0.05 & 48.75 & 4.14 & 0.58 \\
\hline \multirow{4}{*}{ Bioaccumulation factor } & 1 & Cynodon dactylon & 0.12 & 0.29 & 0.54 & 0.28 & 77.27 & 0.39 & 2.20 \\
\hline & 2 & Cynodon dactylon & 0.44 & 0.29 & 0.71 & 0.34 & 4.21 & 0.30 & 0.37 \\
\hline & 1 & Saccharum spontaneum & 0.11 & 0.47 & 0.28 & 0.07 & 8.99 & 0.18 & 1.02 \\
\hline & 2 & Saccharum spontaneum & 0.39 & 0.30 & 0.52 & 0.22 & 2.33 & 0.24 & 0.29 \\
\hline \multirow{2}{*}{$\begin{array}{l}\text { Average concentration in } \\
\text { rhizosheric FA }\left(\mathrm{mg} \mathrm{kg}^{-1}\right)\end{array}$} & 1 & & 255.51 & 15.69 & 71.04 & 0.43 & 4.93 & 22.35 & 1.52 \\
\hline & 2 & & 174.65 & 19.14 & 49.73 & 0.38 & 29.63 & 32.26 & 4.18 \\
\hline
\end{tabular}


Commercially, multiple harvesting is generally done after 3.5 months for oil extraction (Akhila 2010). Thus the plants were harvested after 4 months and noticeably the root: shoot biomass ratios were within the range of $0.8-$ 0.9 (Fig. 5). Highest ratio was observed in treatments with combination of amendments (both top soil and farm yard manure). Moreover, destructive harvest of lemon grass at the end of 4 months showed formation of a vigorous root mass in the shape of a basket around the fly ash as shown in Figure 7a.

\subsection{Ions and metals in leachates obtained from fly ash treatments}

Values obtained from analysis of the leachate samples from fly ash treatments had been compared to the standard drinking water specifications (BIS 10500: 1991). The change in these samples during the growth period of the grass has been represented in Figure 6a-n. Significant differences among the means of the parameters has been shown in Table 5 (supplementary section) to maintain clarity in the corresponding Figure 6a-n. It was observed that garden soil had a significant decreasing effect initially on $\mathrm{pH}$ (Fig. 6a) and alkalinity (Fig. 6e) due to its acidic nature. The $\mathrm{pH}$ of the control leachate was significantly higher than the other treatments all throughout the growth period may be partially due to high root growth of the grass in them (Maiti, Prasad 2016). Overally $\mathrm{pH}$ of $2^{\text {nd }}$ leachate was higher than $1^{\text {st }}$ leachate possibly due to consumption of protons during dissolution of glassy amorphous silicate minerals present in the fly ash (Seoane, Leiros 2001). The combined treatments having both fly ash and garden soil showed the lowest $\mathrm{pH}$ (6.97-7.2) in the later stages leachate again. Studies also suggest that grass roots promote weathering of fly ash and act to loosen the fly ash surface by excretion of saccharides (Neuschutz et al. 2010). Houben et al. (2012) stated that addition of manure increases leachate $\mathrm{pH}$ which was also found in our study, while Oste et al. (2002) concluded that addition of organic amendments reinforces alkalinity in leachates. Though in our study alkalinity was not alarming and was below the desirable limit. Leaching of ions and metals were observed at a significantly greater level in the first leachates as also supported by positive correlation among cations and anions with electrical conductivity which was primarily due to addition of farmyard manure (Fig. 6b). Electrical conductivity decreased to $275-544$ and $197-327 \mu \mathrm{S} \mathrm{cm}^{-1}$ in the $2^{\text {nd }}$ leachate and $3^{\text {rd }}$ leachate respectively. Neuschutz et al. (2010) also observed decreasing electrical conductivity in pots with plant growth as they decrease the release of secondary minerals.

Control leachate had the least total hardness (TH) (96-214 $\mathrm{mg} \mathrm{L}^{-1}$ ) and total dissolved solid (TDS) (149$\left.455 \mathrm{mg} \mathrm{L}^{-1}\right)$, chloride $\left(26-320 \mathrm{mg} \mathrm{L}^{-1}\right)$ and sulphate

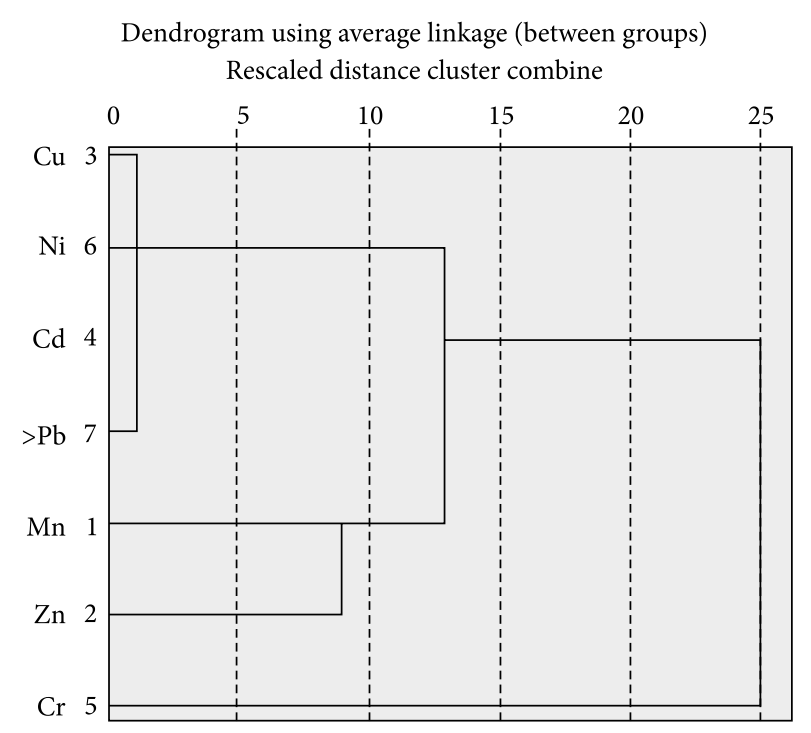

Fig. 4. Hierarchical dendrogram showing clustering of different metals in plants using Pearson correlation as distance and group linkage methods

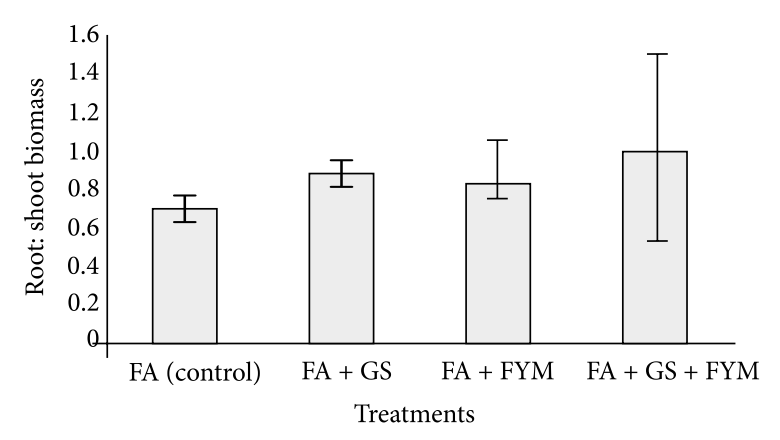

Fig. 5. Root is to shoot biomass ratio of Cymbopogon citratus grown of fly ash treatments compared to control having no amendments

(19-59 $\left.\mathrm{mg} \mathrm{L}^{-1}\right)$ in all the collection periods while treatment leachates had values marginally below the permissible limit in $1^{\text {st }}$ leachates which went below desirable limit in $3^{\text {rd }}$ leachate (decreased by $80 \%$ ) (Fig. $6 c$, d, h, i). On comparison with the control the level of TDS was significantly higher in the treatment leachates and significantly positively correlated to other parameters (Table 3). Leaching of anions from treatments having high level of amendments was mainly due to the presence of high concentration of salts in them also observed by Shimozono et al. (2007). Mukhtar et al. (2003) in their study used high rate of application of farmyard manure as soil amendments which gave apparently high level of total solids in leachates and therefore they also recommended low rate application of farmyard manure to prevent groundwater contamination.

It is known that $\mathrm{Ca}$ is the most largely released cation from fly ash and this depends on its mode of occurrence 

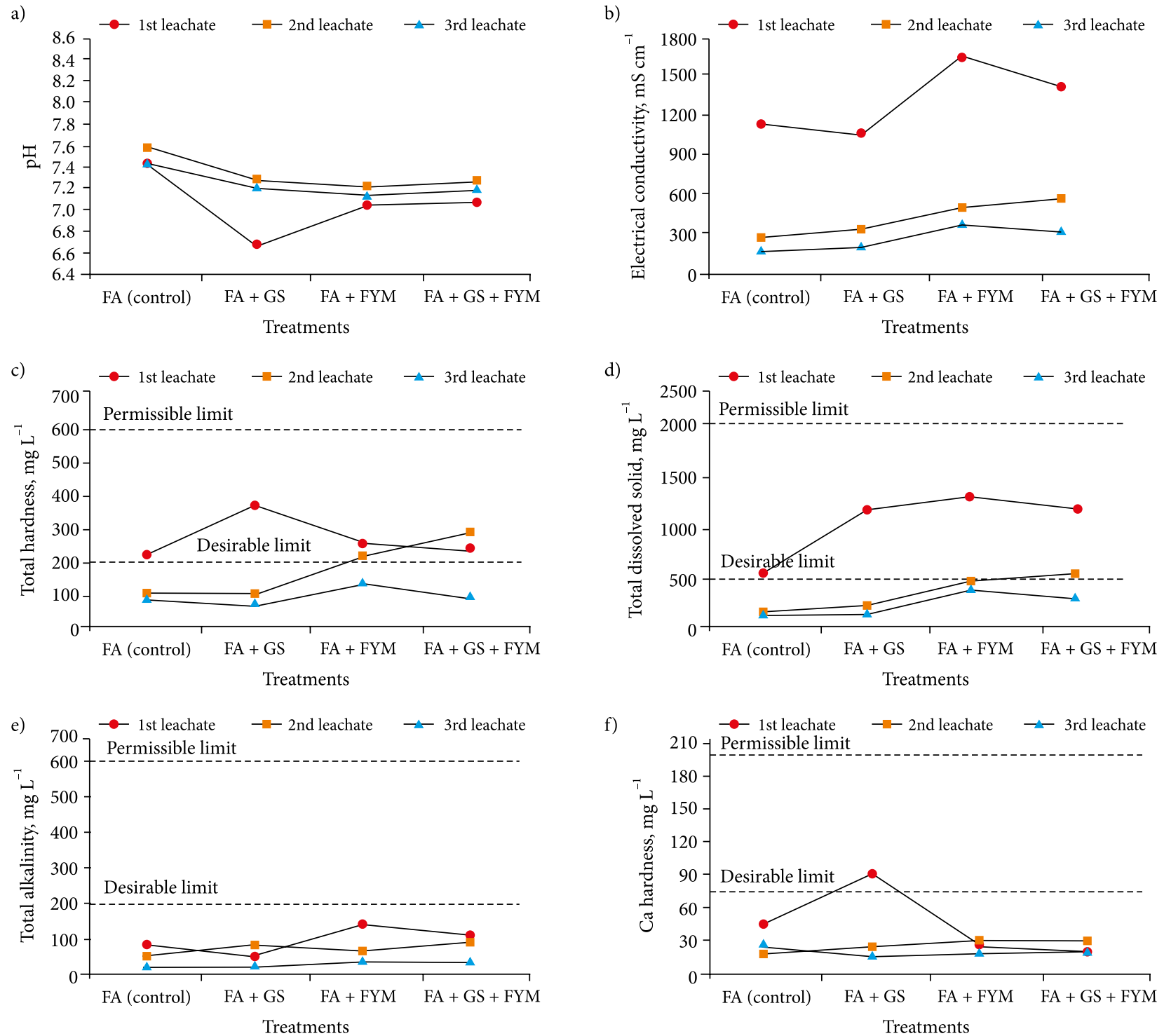

f)
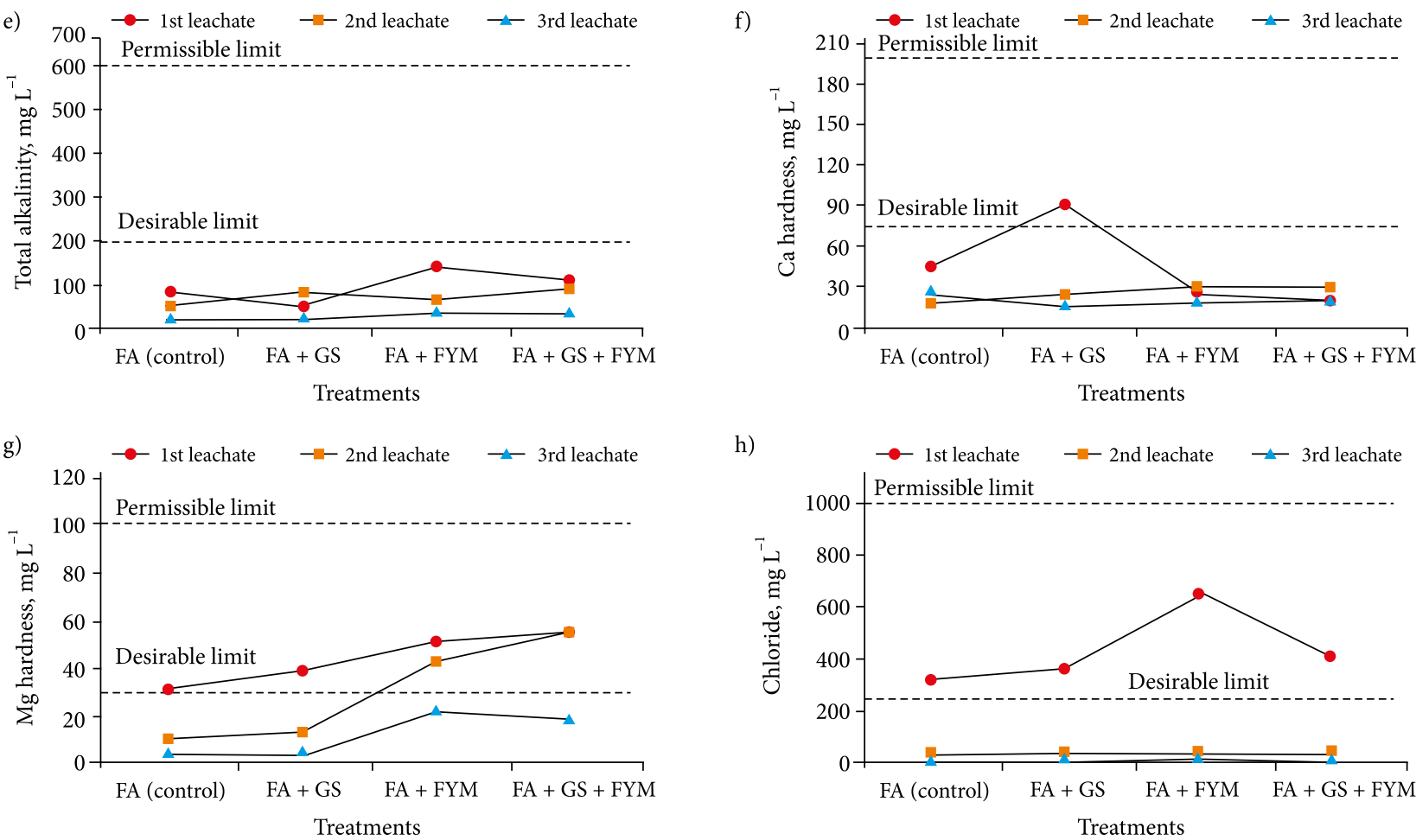

h)
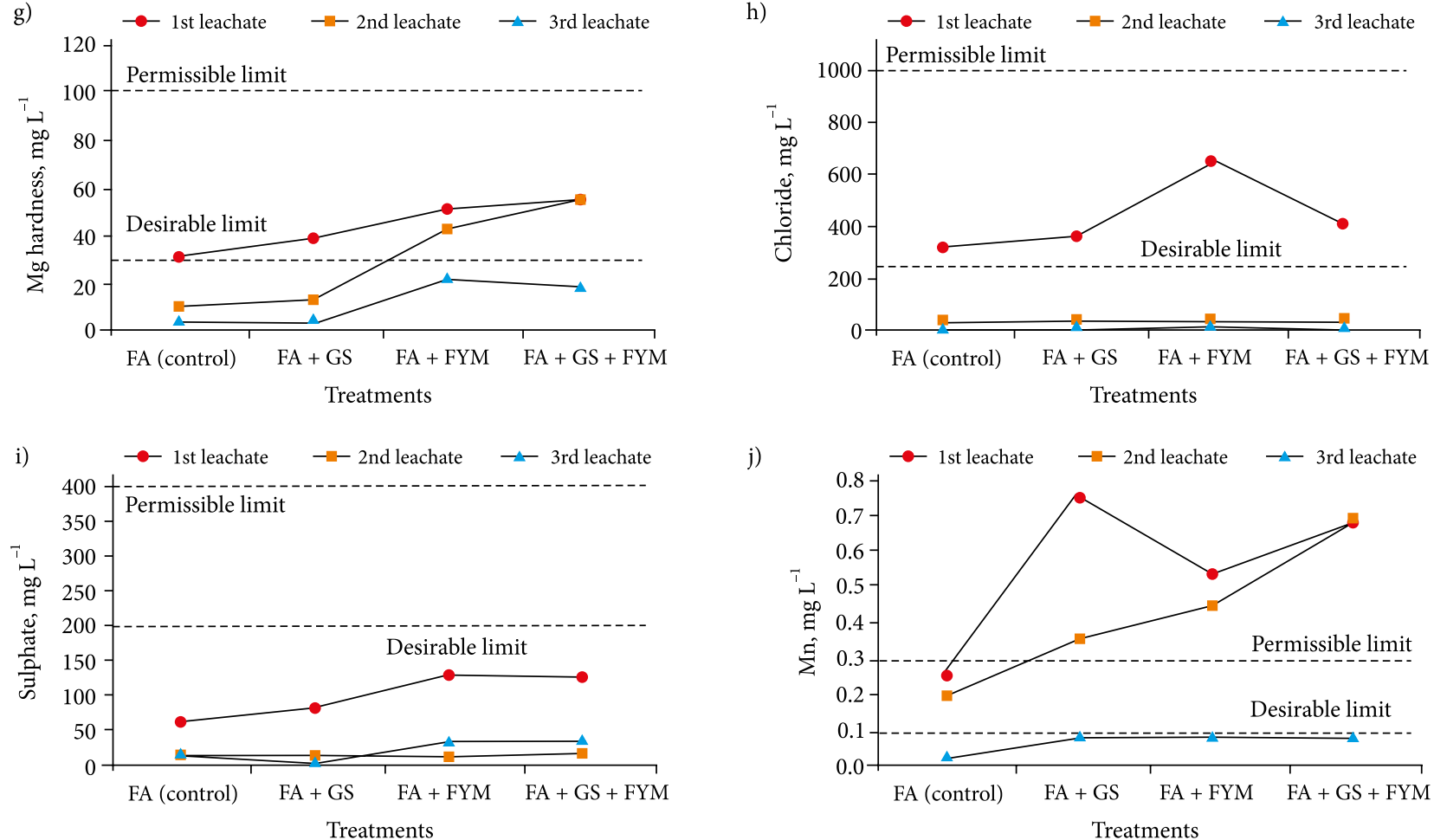

j)

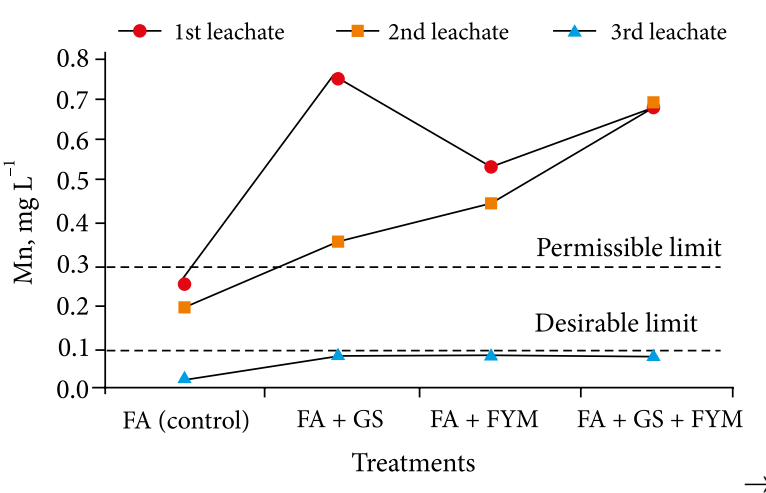



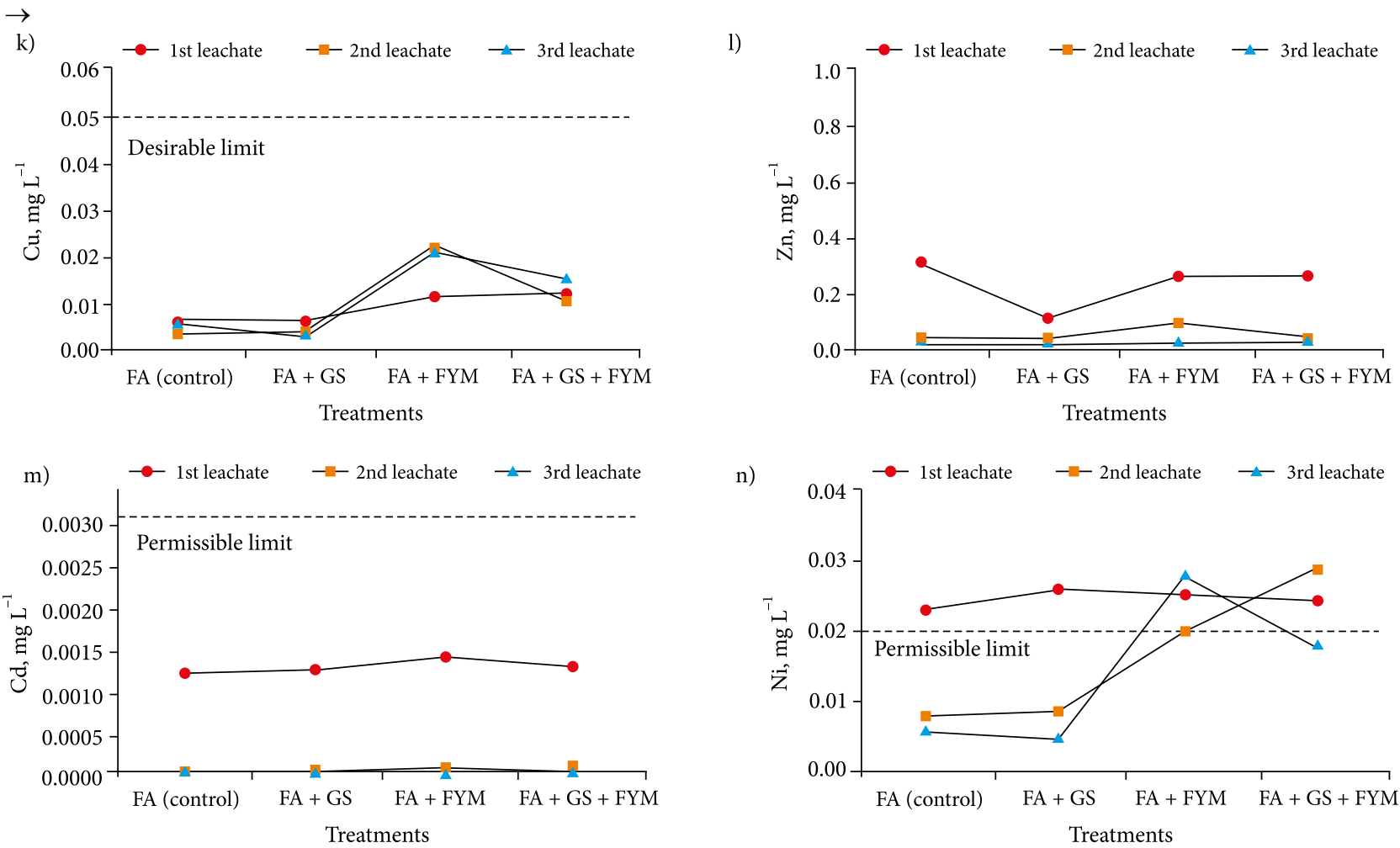

Fig. 6. Characteristics of pot leachates collected at $1^{\text {st }}$ (initial stage), 2 nd stage (3rd month), and $3^{\text {rd }}$ stage ( $4^{\text {th }}$ month or harvest stage) during growth of Cymbopogon citratus on amended fly ash; pH (a) electrical conductivity (EC) (b); total hardness (TH) (c), total dissolved solid (TDS) (d) total alkalinity (e), calcium hardness (Ca H) (f), magnesium hardness (Mg H) (g), chloride (h); sulphate (i) Mn (manganese) (j), Cu (copper) (k), zinc ( $\mathrm{Zn})(\mathrm{l})$, cadmium $(\mathrm{Cd})(\mathrm{m})$, nickel (Ni) (n)

(Izquierdo, Querol 2012). Unlikely in this study, Ca H in all the leachates had a value marginally below desirable limit but a wider variation in release of $\mathrm{Mg}$ was observed (Fig. 6f, g). The pond ash samples collected for the pot study was taken from ash ponds which had already been weathered of the Ca present in it, probably because of being under the influence of water for a long time. Generally, Ca concentration in alkaline FA (like in this study) decreases in a matter of 10 weeks due to precipitation in secondary minerals (Neupane, Donahoe 2013). Ahmad et al. (2009) in their study had concluded that addition of farmyard manure increases leaching of $\mathrm{Mg}$ when compared to other composts. Release of $\mathrm{Mg}$ in this study was also significantly affected by the addition of garden soil and manure and was more pronounced in the combined treatments. Leaching of $\mathrm{Mg}$ continued till the $2^{\text {nd }}$ leachate found above desirable limit and subsequently went down after 4 months in the $3^{\text {rd }}$ leachate.

Amidst all the major cations and anions trace metals are most toxic due to their long term persistence (Prasad, Maiti 2016). In this study metals which have been considered are $\mathrm{Mn}, \mathrm{Cu}, \mathrm{Zn}, \mathrm{Cd}, \mathrm{Ni}, \mathrm{Cr}$, and $\mathrm{Pb}$. Release of these metals in the leachates would finally contaminate the ground water and it was discerned that toxic metals like $\mathrm{Pb}$ and $\mathrm{Cr}$ were below instrument detection limit throughout the pot study. Further, metal concentration was negatively correlated with leachate $\mathrm{pH}$ (Table 4). Cd concentration in $1^{\text {st }}$ leachates $\left(0.0012-0.0013 \mathrm{mg} \mathrm{L}^{-1}\right)$ was also below acceptable limit and subsequently declined below instrument detection limit in $2^{\text {nd }}$ and $3^{\text {rd }}$ leachates (Fig. $6 \mathrm{~m}$ ). Cd was also not significantly different in the leachates at $1^{\text {st }}$ stage.

Among the metals which act as micronutrients for instance $\mathrm{Cu}$ and $\mathrm{Zn}$, leached out in a concentration below acceptable limit (Fig. $6 \mathrm{k}, 1$ ). Level of $\mathrm{Zn}$ in the leachates was not significantly different and was in the range $0.116-0.268 \mathrm{mg} \mathrm{l}^{-1}, 0.033-0.1 \mathrm{mg} \mathrm{L}^{-1}$ and $0.029-$ $0.034 \mathrm{mg} \mathrm{L}^{-1}$ in $1^{\text {st }}, 2^{\text {nd }}$ and $3^{\text {rd }}$ stage respectively, while the concentration decreased in the successive stages. It was noteworthy that $\mathrm{Cu}$ was significantly higher in $2^{\text {nd }}$ $\left(0.022 \mathrm{mg} \mathrm{L}^{-1}\right)$ and $3^{\text {rd }}\left(0.023 \mathrm{mg} \mathrm{L}^{-1}\right)$ leachates from the treatments with only farmyard manure as amendments, while there was no observable decrease in the concentration from initial to final leachate concentration. Mixing of garden soil with farmyard manure complexes or precipitates the metals thus prohibiting their probable release. This may also be due to inherent presence of $\mathrm{Cu}$ in organic matter as farmyard manure itself contains high levels of nutrients.

Contrary to this, $\mathrm{Mn}$ in the leachates was above acceptable limit in the $1^{\text {st }}$ and $2^{\text {nd }}$ leachates. Though the control leachate (only fly ash) depicted $\mathrm{Mn}$ 
(0.034-0.246 $\mathrm{mg} \mathrm{L}^{-1}$ ) above acceptable limit which indeed shows the intrinsic property of the fly ash to release loosely bound $\mathrm{Mn}$, added to this the leachates obtained from amended treatments further had significantly higher concentration of $\mathrm{Mn}$ (0.087-0.753 $\mathrm{mg} \mathrm{L}^{-1}$ ) above permissible limit. This also exhibited that garden soil and farmyard manure contributed to the Mn release in the samples (Fig. 6j). Even among the amended treatments, pots with only garden soil showed significantly highest Mn leaching in $1^{\text {st }}$ stage. Noticeably in the $3^{\text {rd }}$ leachates Mn was found marginally below the acceptable

Table 3. Correlation between general parameters analyzed in leachate samples $(n=81)$

\begin{tabular}{cccccccc}
\hline & $\mathrm{EC}$ & $\mathrm{TH}$ & $\mathrm{TDS}$ & $\mathrm{Ca} \mathrm{H}$ & $\mathrm{Mg} \mathrm{H}$ & $\mathrm{Cl}$ & $\mathrm{SO}_{4}$ \\
\hline $\mathrm{EC}$ & 1 & & & & & & \\
\hline $\mathrm{TH}$ & $0.55^{\star *}$ & 1 & & & & & \\
\hline $\mathrm{TDS}$ & $0.88^{\star *}$ & $0.61^{\star *}$ & 1 & & & & \\
\hline $\mathrm{Ca} \mathrm{H}$ & $0.26^{\star}$ & $0.79^{\star *}$ & $0.29^{\star *}$ & 1 & & & \\
\hline $\mathrm{Mg} \mathrm{H}$ & $0.64^{\star *}$ & $0.92^{\star *}$ & $0.70^{\star *}$ & $0.49^{\star *}$ & 1 & & \\
\hline $\mathrm{Cl}$ & $0.93^{\star *}$ & $0.44^{\star *}$ & $0.82^{\star *}$ & $0.26^{\star}$ & $0.49^{* *}$ & 1 & \\
\hline $\mathrm{SO}_{4}$ & $0.89^{\star *}$ & $0.43^{\star *}$ & $0.83^{\star *}$ & 0.07 & $0.57^{\star *}$ & $0.85^{\star *}$ & 1 \\
\hline
\end{tabular}

Notes: EC: electrical conductivity, TH: total hardness, TDS: total dissolved solid, $\mathrm{Ca} \mathrm{H}$ : calcium hardness, $\mathrm{Mg} \mathrm{H}$ : magnesium hardness, Cl: chloride, SO4: sulphate.

${ }^{\star}$ Correlation is significant at the 0.05 level (2-tailed).

${ }^{* *}$ Correlation is significant at the 0.01 level (2-tailed).

Table 4. Correlation between metals analyzed in leachate samples $(n=81)$

\begin{tabular}{ccccccc}
\hline & $\mathrm{pH}$ & $\mathrm{Mn}$ & $\mathrm{Cu}$ & $\mathrm{Zn}$ & $\mathrm{Cd}$ & $\mathrm{Ni}$ \\
\hline $\mathrm{pH}$ & 1 & & & & & \\
$\mathrm{Mn}$ & -0.19 & 1 & & & & \\
$\mathrm{Cu}$ & -0.13 & 0.05 & 1 & & & \\
$\mathrm{Zn}$ & -0.19 & 0.14 & -0.09 & 1 & & \\
$\mathrm{Cd}$ & $-0.38^{\star *}$ & $0.26^{\star}$ & -0.09 & $0.61^{\star *}$ & 1 & \\
$\mathrm{Ni}$ & -0.15 & $0.65^{\star *}$ & $0.56^{\star *}$ & 0.13 & 0.15 & 1 \\
\hline
\end{tabular}

Notes: ${ }^{\star}$ Correlation is significant at the 0.05 level (2-tailed). ${ }^{*}$ Correlation is significant at the 0.01 level (2-tailed).

a)

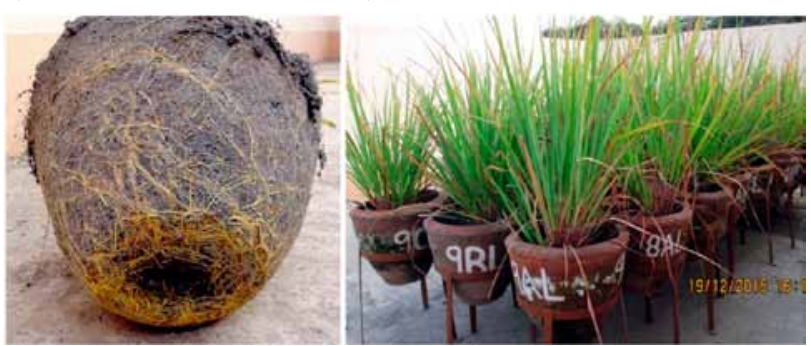

Fig. 7. Growth of lemon grass after 4 months of plantation (a), massive root growth of lemon grass which stabilizes the fly ash (b) limit $\left(0.1 \mathrm{mg} \mathrm{L}^{-1}\right)$. Ni concentration also varied arbitrarily in the 3 stages and was significantly above permissible limit in the amended treatments when compared to the control $\left(0.006-0.023 \mathrm{mg} \mathrm{L}^{-1}\right)$. More amount of the metal was observed in those treatments with only garden soil (0.004-0.026 $\left.\mathrm{mg} \mathrm{L}^{-1}\right)$ or farmyard manure (0.020$0.027 \mathrm{mg} \mathrm{L}^{-1}$ ) which shows the presence of $\mathrm{Ni}$ in garden soil as well as farmyard manure. In fact, garden soil treatments showed a peak concentration of $\mathrm{Ni}$ in 1 st leachates which lowered down in later stages whereas farmyard manure treatments gave constant elevated levels of $\mathrm{Ni}$ in all the stages. Yet treatments with both the amendments (garden soil and farmyard manure) depicted concentration below permissible level till the end exhibiting some precipitation of Ni. Metal levels in the leachates also showed some significant positive correlations between $\mathrm{Mn}, \mathrm{Ni}$; and $\mathrm{Cu}$, Ni likewise observed by Edet and Offong (2002) in their study.

Moreover, at the time of harvest, leachates (3L) of all the treatments had homogeneous values for all parameters below or marginally around the desirable limit which is not an alarming issue regarding ground water contamination. Fly ash is known to have sufficient quantities of inorganic nutrients which can support plant growth. Therefore addition of lower percentage of easily available NPK supplements in the form of garden soil and farmyard manure can boost the growth of economically valuable aromatic grasses. Further, in previous studies workers have used high rate of amendments for ecorestoration of contaminated sites which can drastically affect the water quality beneath the ground. In this study the treatment with farmyard manure have proved their efficiency by enhancing the growth of $C$. citratus i.e high root: shoot biomass ratio. They can be successfully implemented in the field for revegetation of fly ash dumps without any possibilities of ground water contamination.

Conclusively, the perennial nature of C. citratus (Fig. 7b), unpalatability to grazing animals and high commercial end uses makes it an efficient plant species for restoration of fly ash disposal sites.

\section{Conclusions}

A reclamation strategy of fly ash disposal sites encompasses discussion on fly ash characteristics, followed by selection of type of amendment and its application rate as well as the plant species. Native and invasive species are an effective choice at initial stages. Apart from increment in fertility of the sites, fly ash surface stabilisation was adequately achieved which was the foremost goal in this context. This was proved from the present status of fly ash dumps in Damoda abandoned mines. Despite of less after care and maintenance species such as Cynodon dactylon, and Saccharum spontaneum, were 
found to colonize the dump creating a thick vegetation mat. Metal bioaccumulation studies proved that on virtue of high biomass potential of Saccharum spontaneum than C. dactylon it can also be used as phytoextractor of toxic metals and thus phytoremediate the metals in fly ash. Added to this, the pot scale study with amended fly ash showed that Cymbopogon citratus efficiently grew in low nutrient conditions and stabilized the fly ash volume through its extensive root system. It is another fruitful choice for revegetation of fly ash disposal sites. Initial leaching studies on the treatments have also supported the effectiveness of the dual amended treatments to be used in the field. The ephemeral effects on leachates due to addition of farm yard manure diminished in a matter of 4 months and acceptably the values were below permissible limit as per drinking water standards. A properly planned reclamation programme can thus be made by incorporating economically useful plant species such as C. citratus at later stages. Lastly a regular monitoring schedule is of prime importance in each restoration programme which will help in predicting long term change in fly ash properties due to vegetation and guide the future steps to improve the status of the sites.

\section{Acknowledgements}

Authors are grateful to Dr. Pradeep Kumar Singh, Director, CSIR - Central Institute of Mining and Fuel Research, Dhanbad, India for the continuous support and motivation during the investigation period. First author is thankful to (Department of Science and Technology, Government of India) DST for the (Innovation in Science Pursuit for Inspired Research) INSPIRE fellowship provided to her.

\section{References}

Ahmad, Z.; Honna, T.; Yamamoto, S.; Irshad, F. M.; Waleed, H. A. E. 2009. Effect of chloride and sulfate salinity on micronutrients release and uptake from different composts applied on total phosphorus basis, Communication in Soil Science and Plant Analysis 40: 1566-1589.

http://dx.doi.org/10.1080/00103620902831644

Akhila, A. 2010. Essential oil-bearing grasses: the genus Cymbopogon. Medical and aromatic plants-industrial profile. Taylor and Francis Group: LLC.

APHA; AWWA; WEF. 1992. Standard methods for the examination of water and wastewater. $18^{\text {th }} \mathrm{ed}$. Washington: DC.

ASTM D 2974-87:2000. Standard test methods for moisture, ash, and organic matter of peat and other organic soils. American Society for Testing and Materials, USA.

Babu, A. G.; Reddy, M. S. 2011. Dual inoculation of arbuscular mycorrhizal and phosphate solubilising fungi contributes in sustainable maintenance of plant health in fly ash ponds, $\mathrm{Wa}$ ter, Air, and Soil Pollution 219: 3-10. http://dx.doi.org/10.1007/s11270-010-0679-3
Belyaeva, N. O.; Haynes, J. R. 2012. Comparison of the effects of conventional organic amendments and biochar on the chemical, physical and microbial properties of coal fly ash as a plant growth medium, Environmental Earth Sciences 66: 1987-1997. http://dx.doi.org/10.1007/s12665-011-1424-y

BIS IS 10500:1991. Drinking water specifications. First revision. Bureau of Indian Standards, India.

CEA. 2012. Annual Report on Fly-ash utilization. Report on fly ash generation at coal/lignite based thermal power stations and its utilization in the country for the year 2011-12 [online], [cited 8 December 2015]. New Delhi. Available from Internet: http://cea.nic.in/reports/others/thermal/tcd/flyash_ final_1415.pdf

Cheung, K. C.; Wong, J. P. K.; Zhang, Z. Q.; Wong, J. W. C.; Wong, M. H. 2000. Revegetation of lagoon ash using the legume species Acacia auriculiformis and Leucaena leucocephala, Environmental Pollution 109: 75-82. http://dx.doi.org/10.1016/S0269-7491(99)00235-3

Das, S.; Ram, S. S.; Sahu, H. K.; Rao, D. S.; Chakraborty, A.; Sudarshan, M.; Thatoi, H. N. 2013. A study on soil physicochemical, microbial and metal content in Sukinda chromite mine of Odisha, India, Environment Earth Science 69: 24872497. http://dx.doi.org/10.1007/s12665-012-2074-4

Dwivedi, S.; Srivastava, S.; Mishra, S.; Dixit, B.; Kumar, A.; Tripathi, R. D. 2008. Screening of native plants and algae growing on fly-ash affected areas near National Thermal Power Corporation, Tanda, Uttar Pradesh, India for accumulation of toxic heavy metals, Journal of Hazardous Materials 158: 359-365. http://dx.doi.org/10.1016/j.jhazmat.2008.01.081

Edet, A. E.; Offiong, O. E. 2002. Evaluation of water quality pollution indices for heavy metal contamination monitoring. A study case from Akpabuyo-Odukpani area, Lower Cross River Basin (southeastern Nigeria), GeoJournal 57: 295-304. http://dx.doi.org/10.1023/B:GEJO.0000007250.92458.de

Graham, D. B.; Josef, N. S. K.; Kristin, S. 2014. The reproductive biology of Saccharum spontaneum L.: implications for management of this invasive weed in Panama, NeoBiota 20: 61-79. http://dx.doi.org/10.3897/neobiota.20.6163

Gupta, A. K.; Sinha, S. 2008. Decontamination and/or revegetation of fly ash dykes through naturally growing plants, Journal of Hazardous Materials 153: 1078-1087. http://dx.doi.org/10.1016/j.jhazmat.2007.09.062

Gupta, D. K.; Rai, U. N.; Tripathi, R. D.; Inouhe, M. 2002. Impacts of fly ash on soil and plant responses, Journal of Plant Research 115: 401-409. http://dx.doi.org/10.1007/s10265-002-0057-3

Haynes, R. J. 2009. Reclamation and revegetation of fly ash disposal sites - challenges and research needs, Journal of Environmental Management 90: 43-53. http://dx.doi.org/10.1016/j.jenvman.2008.07.003

Houben, D.; Pircar, J.; Sonnet, P. 2012. Heavy metal immobilization by cost-effective amendments in a contaminated soil: effects on metal leaching and phytoavailability, Journal of Geochemical Exploration 123: 87-94. http://dx.doi.org/10.1016/j.gexplo.2011.10.004

Hrynkiewiez, K.; Baum, C.; Niedojadlo, J.; Dahm, H. 2009. Promotion of mycorrhiza formation and growth of willows by the bacterial strain Sphingomonas sp. 23 L on fly ash, Biology and Fertility of Soils 45: 385-394. http://dx.doi.org/10.1007/s00374-008-0346-7 
IS-3025:2009. Methods of sampling and test (physical and chemical) for water used in industry. Bureau of Indian Standard, India.

Izquierdo, M.; Querol, X. 2012. Leaching behaviour of elements from coal combustion fly ash: an overview, Intinternational Journal of Coal Geology 94: 54-66.

http://dx.doi.org/10.1016/j.coal.2011.10.006

Jackson, M. L. 1973. Soil chemical analysis. New Delhi: Prentice Hall of India.

Jain, K. A.; Gaggar, S. 2013. Present status of availability, utilization and other options to increase effective use of fly ash in India, in $3^{\text {rd }}$ Annual International Summit: Fly Ash Utilisation, 17-18 December 2013, New Delhi, India.

Jamil, S.; Abhilash, P. C.; Singh, N.; Sharma, P. N. 2009. Jatropha curcas: a potential crop for phytoremediation of coal fly ash, Journal of Hazardous Materials 172: 269-275. http://dx.doi.org/10.1016/j.jhazmat.2009.07.004

Kaith, B. S.; Jindal, R.; Jana, A. K.; Maiti, M. 2010. Development of corn starch based green composites reinforced with Saccharum spontaneum L. fiber and graft copolymers - Evaluation of thermal, physicochemical and mechanical properties, Bioresource Technology 101: 6843-6851.

http://dx.doi.org/10.1016/j.biortech.2010.03.113

Krzaklewski, W.; Pietrzykowski, M.; Wos, B. 2012. Survival and growth of alders Alnus glutinosa (L.) Gaertn. and Alnus incana (L.) Moench on fly ash technosols at different substrate improvement, Ecological Engineering 49: 35-40. http://dx.doi.org/10.1016/j.ecoleng.2012.08.026

Maiti, D.; Prasad, B. 2016. Revegetation of fly ash-a review with emphasis on grass-legume plantation and bioaccumulation of metals, Applied Ecology and Environmental Research 14(2): 185-212. http://dx.doi.org/10.15666/aeer/1402_185212

Maiti, S. K.; Jaiswal, S. 2008. Bioaccumulation and translocation of metals in the natural vegetation growing on fly ash deposits: a field study from Santaldih thermal power plant, West Bengal, India, Environment Monitoring Assessment 136: 355-370. http://dx.doi.org/10.1007/s10661-007-9691-5

Maiti, S. K.; Maiti, D. 2015 Ecological restoration of waste dumps by topsoil blanketing, coir-matting and seeding with grasslegume mixture, Ecological Engineering 77: 74-84. http://dx.doi.org/10.1016/j.ecoleng.2015.01.003

Marseille, F.; Tiffreau, C.; Laboudigue, A.; Lecomte, P. 2000. Impact of vegetation on the mobility and bioavailability of trace elements in a dredged sediment deposit: a greenhouse study, Agronomie 20: 547-556. http://dx.doi.org/10.1051/agro:2000149

Mathur, R.; Chand, S.; Tezuka, T. 2003. Optimal use of coal for the power generation in India, Energy Policy 31: 319-331. http://dx.doi.org/10.1016/S0301-4215(02)00067-8

Mishra, D. P.; Das, S. K. 2010. A study of physico-chemical and mineralogical properties of Talcher coal fly ash for stowing in underground coal mines, Materials Characterization 61: 1252-1259. http://dx.doi.org/10.1016/j.matchar.2010.08.008

Mukhopadhyay, S.; Maiti, S. K.; Masto, R. E. 2013. Use of Reclaimed Mine Soil Index (RMSI) for screening of tree species for reclamation of coal mine degraded land, Ecological Engineering 57: 133-142. http://dx.doi.org/10.1016/j.ecoleng.2013.04.017

Mukhtar, S.; Kenimer, A. L.; Sadaka, S. S.; Mathis, J. G. 2003. Evaluation of bottom ash and composted manure blends as a soil amendment material, Bioresource Technology 89: 217228. http://dx.doi.org/10.1016/S0960-8524(03)00085-3

Neupane, G.; Donahoe. R. J. 2013. Leachability of elements in alkaline and acidic coal fly ash samples during batch and column leaching tests, Fuel 104: 758-770. http://dx.doi.org/10.1016/j.fuel.2012.06.013

Neuschutz, C.; Bostrom, D.; Greger. M. 2010. Root growth into sealing layers of fly ash, Journal of Plant Interaction 5: 75-85. http://dx.doi.org/10.1080/17429141003592853

Oste, L. A.; Temminghoff, E. J. M.; Van Riemsdijk. W. H. 2002. Solid-solution partitioning of organic matter in soils as influenced by an increase in $\mathrm{pH}$ or Ca concentration, Environment Science Technology 36: 208-214. http://dx.doi.org/10.1021/es0100571

Page, A. L.; Elseewi, A. A.; Straughan, I. R. 1979. Physical and chemical properties of fly-ash from coal-fired power plants with reference to environmental impacts, Residue Review 71: 83-120. http://dx.doi.org/10.1007/978-1-4612-6185-8_2

Pandey, V. C. 2012. Invasive species based efficient green technology for phytoremediation of fly ash deposits, Journal of Geochemical Exploration 123: 3-18.

http://dx.doi.org/10.1016/j.gexplo.2012.05.008

Pandey, V. C. 2013. Suitability of Ricinus communis L. Cultivation for phytoremediation of fly ash disposal sites, Ecological Engineering 57: 336-341. http://dx.doi.org/10.1016/j.ecoleng.2013.04.054

Pandey, V. C.; Singh, K.; Singh, R. P.; Singh, B. 2012. Naturally growing Saccharum munja L. on the fly ash lagoons: a potential ecological engineer for the revegetation and stabilization, Ecological Engineering 40: 95-99. http://dx.doi.org/10.1016/j.ecoleng.2011.12.019

Piper, C. S. 1942. Soil and plant analysis. The University of Adelaide, Adelaide, Australia. 368 p.

Prasad, B.; Maiti, D. 2016. Comparative study of metal uptake by Eichhornia crassipes growing in ponds from mining and nonmining areas - a field study, Bioremediation Journal 20: 144-152. http://dx.doi.org/10.1080/10889868.2015.1113924

Punshon, T.; Adriano, D. C.; Weber, J. T. 2002. Restoration of drastically eroded land using coal fly ash and poultry biosolid, The Science of the Total Environment 296: 209-225. http://dx.doi.org/10.1016/S0048-9697(02)00128-6

Ram, L. C.; Jha, S. K.; Tripathi, R. C.; Masto, R. E., Selvi, V. A. 2008. Remediation of fly ash landfills through plantation, Remediation 18: 71-90. http://dx.doi.org/10.1002/rem.20184

Seoane, S.; Leiros, M. C. 2001. Acidification-neutralization processes in a lignite mine spoil amended with fly ash or limestone, Journal of Environment Quality 30: 1420-1431. http://dx.doi.org/10.2134/jeq2001.3041420x

Shaheen, S. M.; Hooda, P. S.; Tsadilas, C. D. 2014. Opportunities and challenges in the use of coal fly ash for soil improvements - a review, Journal of Environmental Management 145: 249-267. http://dx.doi.org/10.1016/j.jenvman.2014.07.005

Shimozono, N.; Fukuyama, M.; Kawaguchi, M.; Iwaya Inoue, M.; Molla, A. H. 2007. Nutrient dynamics through leachate and turf grass growth in sands amended with food-waste compost in pots, Communication in Soil Science and Plant Analysis 39: 241-256. http://dx.doi.org/10.1080/00103620701759251

Subbiah, B. V.; Asija, G. L. 1956. A rapid procedure for the determination of available nitrogen in soils, Current Science 25: 259-260. 
Zolnierz, L.; Weber, J.; Gilewska, M.; Strączynska, S.; Pruchniewicz, D. 2016. The spontaneous development of understory vegetation on reclaimed and afforested post-mine excavation filled with fly ash, Catena 136: 84-90. http://dx.doi.org/10.1016/j.catena.2015.07.013

Deblina MAITI. MSc, DST - INSPIRE Fellow (Senior Research Fellow), Academy of Scientific and Innovation Research, CSIR - Central Institute of Mining and Fuel Research, Dhanbad, Jharkhand, India. Research interests: Ecorestoration of fly ash landfills, Phytoremediation, Soil chemistry.

Bably PRASAD. PhD, Senior Principal Scientist, Natural Resources and Environmental Management, CSIR - Central Institute of Mining and Fuel Research, Dhanbad, Jharkhand, India. Research interests: Water pollution and treatment, Acid Mine drainage, Environmental Impact of Fly ash. 